\title{
Középjátékosok, centerek távoli dobásainak jelentősége, avagy ma már mindenkinek van hárompontos dobáskísérlete a kosárlaboában
}

\section{Significance of long-range shots among power forwards and centers; nowadays every player has three point attempts in basketball}

\author{
Boros Zoltán', Sterbenz Tamás²
}

Testnevelési Egyetem, 1 Sportjáték Tanszék, 2 Sportgazdaságtani és Döntéstudományi Kutató Központ

\begin{abstract}
Absztrakt - A kosárlabda mérkőzések elemzése során figyelembe vett statisztikai adatok alapján egyértelmúen kijelenthetó, hogy ma a kosárlabda mérkózések meghatározó játékelemévé nótte ki magát a centerek hárompontos kísérleteinek száma és eredményessége. Az olimpiák történetben először 1988-ban Szöulban lehetett 3 pontos kosarat szerezni a kosárlabda mérkózéseken. Ha különválasztjuk a mezónyjátékosok és a centerek hárompontos kísérleteinek a számát a mérkózéseken, látható, hogy a csapatok játékosai 1380-szor próbálkoztak távoli dobással. Ebben a centerek 26\%-os hatékonysággal vettek részt, ami a Rio de Janeiro-i olimpián (2016) már 37\%-os volt. Szöulban az összes sikeres hárompontos dobásnak csak 1\%-t dobták a centerek, míg Rio-ban ez már 17\% volt, ami jelentósnek mondható. Ennek az eredménynek egyik fontos meghatározó tényezóje, hogy a hivatalosan 144 regisztrált játékos közül, Szöulban 18, míg Rióban már 51 center szerepelt a csapatokban. Az eredményekból látszik, hogy az elmúlt négy olimpián a mezönyjátékosoknak megközelítóleg átlagosan ötször annyi hárompontos dobáskísérletük volt, mint a centereknek, viszont nem mindegy milyen hatékonysággal történt ez. Például, ha nem is nagy különbséggel, de a Rio-i olimpián a centerek jobbnak bizonyultak ebben az összehasonlításban; a mezónyjátékosok 33, míg a centerek 37\%-os hatékonysággal céloztak a hárompontos vonalon túlról. A tendencia azt mutatja, hogy a távoli kísérletek számának növekedésével nótt a sikeres dobások száma, de nem csak a számok, hanem a hatékonyság szempontjából is. Ha nem is minden évben, de hosszú távon emelkedést mutat a hatékonyság. Az olimpiai játékok statisztikai mutatói alapján megállapítható, hogy a hárompontos dobások kísérleteinek és hatékonyságának növekedésében a centerek fontos szerepet játszanak.
\end{abstract}

Kulcsszavak: kosárlabda, center, hárompontos dobás, hatékonyság, statisztika

\begin{abstract}
When analyzing basketball statistics it can be declared that the three point shots and the points scored from them have become a major factor in today's game. It was the first time in Seoul in 1988, that in basketball the three-point line was drawn; it gave a new powerful tool into the hands of the players. During this competition if we take the number of three-point attempts, it can be seen that from the overall 1380 shots only $26 \%$ was executed by the centers. However two years ago in the Rio Olympics this number reached $37 \%$. As for the successful shots: in Seoul only $1 \%$ of the three pointers was achieved by the players in position five. In Rio this number was $17 \%$ which is a significant improvement. It has to be mentioned that in Seoul from the altogether 144 players 18 were playing as a center, while in Rio this number was 51. In the last four Olympic Games it could be seen that guards have averaged five times more three-point shot attempts than the power forwards and the centers, but in shot effectiveness there was a difference in the numbers. For example, in Rio the guards succeeded in $33 \%$ of their three-point attempts, and the centers could beat this number by $4 \%$, so they took 5 times less shots but still succeeded in 37\% percent of them. The tendency shows us that the overall number of
\end{abstract}


three-point attempts have increased together with the number of successful shots (shot efficiency). But this is a slow process on the long run. Based on the statistics of the Olympic Games, it can be stated that centers and power forwards have important roles in growth of shot efficiency.

Keywords: basketball, center, three-point shots, efficiency, statistics

\section{Bevezetés}

Az 1979-ben bevezetett hárompontos szabály ötletének kivitelezése már évtizedekkel korábban megszületett. Howard Hobson amerikai egyetemi edző javaslatára kísérletképpen festették fel a hárompontos vonalat 1945-ben a ColumbiaFordham mérkőzésen. Az ötlet onnan eredt, hogy egyre inkább a magas emberek domináltak a kosárlabdapályán a kosárszerzésben, a kisebb játékosok kiszorultak a gyürủ alól a támadó terület külső részeire és kevésbé voltak eredményesek. A hárompontos vonalon túli sikeres dobások felértékelődése viszont kompenzálhatja termetüket.

Nem volt teljes az elfogadottsága ennek az új szabály-kezdeményezésnek, bár a kérdés majdnem minden évben újra felmerült. Csak a hatvanas évek vége felé, az 1967-68-as bajnoki szezonban vezették be az ABA ligában (American Basketball Associaton), ami az NBA-vel (National Basketball Associaton) párhuzamosan müködő bajnokságként működött. Céljuk az volt, hogy izgalmasabbá és látványosabbá váljanak a mérkőzések, nagyobb szerepet kapjanak a külső mezőnyjátékosok is távoli dobásaik értéknövelésével, illetve a csapatoknak védekezésében is fejlődést lehessen elérni a nagyobb figyelemmegosztás miatt, azzal hogy jobban ki kell húzódni a gyűrűtől távolabb elhelyezkedő külső dobójátékosokra.

Az utóbbi évtizedek olimpiáin kosárlabdában hagyományosan az Egyesült Államok csapatai diadalmaskodtak, ahol a kosárlabda őshazája van, és ahol akár egyetemi vagy professzionális szinten mindig is a világ legerősebb, legszínvonalasabb bajnoksága zajlik. A saját professzionális bajnokságukban, az NBA-ben 1979-ben vezették be a hárompontos dobást. A bevezetés óta a mérkőzéseken a hárompontos kísérletek száma folyamatosan növekvő tendenciát mutat. Az 1982-es bajnok Los Angeles Lakers az egész alapszakaszban 13 hárompontost dobott, a 2015/16-os szezonban a Golden States Warriors egy meccsen dobott ennyit, átlagban 41\%-os hatékonysággal. Az 1992/93-as szezonban, amely az NBA aranykorának is talán legjobb évada volt (a Dream Team olimpiai aranya utáni szezon), liga szinten a dobások $10 \%$-a volt tripla. A 2016/17-es szezonban ugyanez a szám $28 \%$ volt, tehát közel minden harmadik vagy negyedik dobáskísérlet lett hárompontos. A mai edzői filozófia szerint, ha nem lehet ziccert, vagy büntetőt dobni, akkor dobjunk hármast, mert az a következő leghatékonyabb dobás - ezt statisztikák támasztják alá (Oliver, 2004). A tendencia azt mutatja, hogy a távoli kísérletek számának növekedésével párhuzamosan nőtt a sikeres dobások száma is, de nem csak a számok alapján, hanem a hatékonyság szempontjából is. Ha nem is minden évben nő a hatékonyság, de hosszú távon emelkedést mutat. A jelenlegi szezonban, NBA ligaszinten, 35 az átlag a dobószázalék (nba.com). Mivel korábban jellemzően csak a mezőnyjátékosoknak voltak hárompontos dobásaik, a cikk azt vizsgálja, hogy hogyan változtak az elmúlt évtizedekben a centerek hárompontos dobásai a kosárlabda mérkőzéseken. A tapasztalatok alapján feltételezheto", hogy a hárompontos dobások kísérleteinek és hatékonyságának növekedésében nagy szerepet játszanak a centerek (a csapatok magasabb, gyürühöz közelebbi 4-es és 5-ös poszton játszó középjátékosok), amit az olimpiai játékok statisztikai mutatói egyértelműen alátámasztanak.

$\mathrm{Az}$ amerikai férfi professzionális kosárlabda bajnokság (NBA) mintájára, ahol a hárompontos vonal 7,24 méterre van a gyürűtől, 1984-bena Nemzetközi Kosárlabda Szövetség (FIBA) is bevezette a hárompontos kosárszerzés lehetőségét. 6,25méteren határozták meg a távolságot, amit 2010-ben 6,75-re módosítottak. A csapatok támadó-taktikai repertoárja kibővült és ez maga után vonta a csapatok védekezési stratégiájának felépítettségét is. Évtizedekig jellemzően a külső mezőnyjátékosoknak voltak hárompontos dobáskísérlete. A centerek csak elvétve, egy-egy alkalommal próbálkoztak a mérkőzés alatt, vagy legfeljebb a már 
elöre láthatóan „megnyert” mérkőzések végén még egyszer, amikor már nem volt akkora kockázata, ha a középjátékos dobása kimaradt. Ennek oka a korábbi támadási játékrendszerek alapfelállásában és mozgásirányaiban keresendő, mivel a centerekre a kosárlabda gyűrűhöz közeli, a mezőnyjátékosokra pedig a gyürütől távolabbi pozíciókban való elhelyezkedés volt jellemző. Az akkori centerek egyéni képességei miatt sem kísérleteztek távolról, nem voltak olyan ,jó kezü" 'játékosok, illetve a támadásokban mindig a „kicsi kinn, nagy benn”2 elv uralkodott. Ennek következményeként, az edzéseken a dobások gyakorlása a mérkőzés szituációknak megfelelően ez alapján történtek. Az NBA előszobája az amerikai egyetemi bajnokság (NCAA). A legendás UCLA amerikai egyetem edzője, John R. Wooden

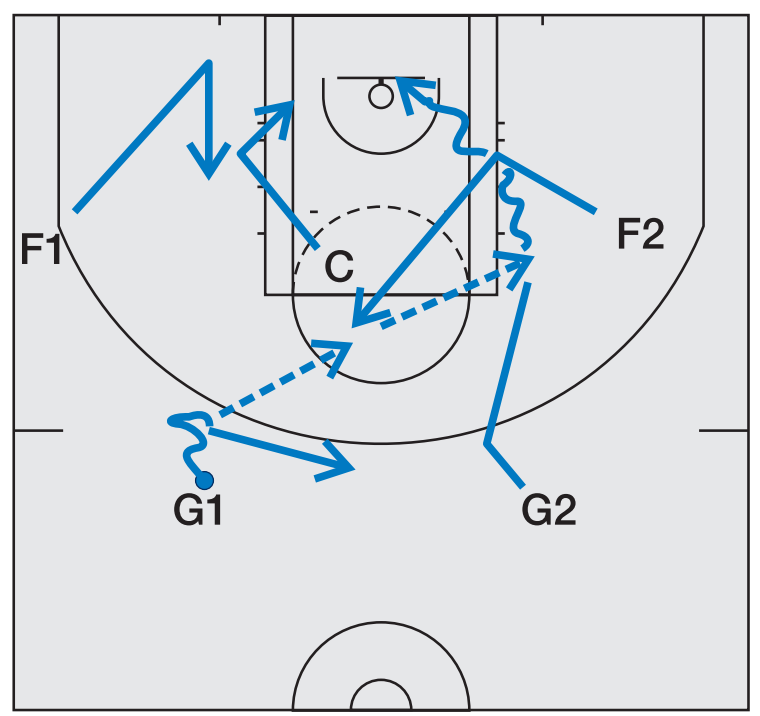

Center: C; Mezönyök: F1, F2; Bedobók: Irányitó: G1; Dobóhátvéd: G2
(1999) könyvében a sokfajta támadási rendszerből két példa is mutatja a támadási mozgásirányokat, az egy centeres (single post) és kétcenteres (double post) rendszerekben. Az 1970-as években (1. ábra). Jerry Krause (1994) könyvében a North Carolina egyetem (többszörös egyetemi bajnokcsapat), az 1980-as évek támadó alapfelállásai alátámasztják, hogy a centerek hol helyezkedtek el leggyakrabban a támadások során. A centerek a belső, gyűrűhöz közeli pozíciókban vannak, míg az irányítók, hátvédek, bedobók a hárompontos vonalon kívül. (1. ábra). Az egyetem csapatának híres edzője, Dean Smith (1961-97-ig volt az egyetemi csapat edzője, itt játszott Michael Jordan) a centerek alsó (low post) és felső poszt (high post) támadási mozgástereit is szemlélteti. (2. ábra).

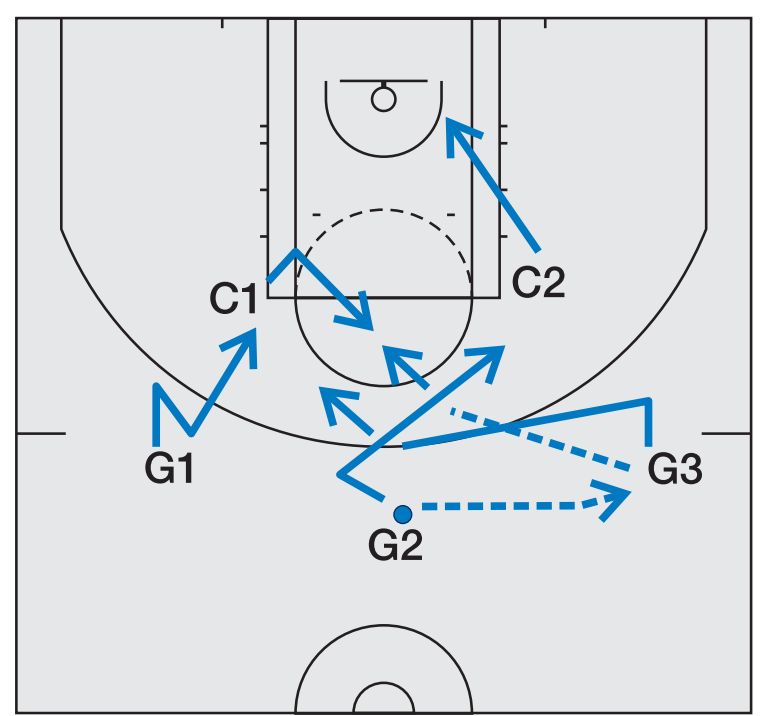

Centerek: C1, C2; Mezönyök: G1, G2, G3

1. ábra. Egycenteres (single post) és kétcenteres (double post) támadó mozgásirányok (eredeti ábra: J. R. Wooden, Practical Modern Basketball 178.o. Diagram 4-46 Single Post; 182.o., Diagram 4-53 Double Post \#7- Off Side Cut., 1999)

A mai modern kosárlabdában már az alapfelállások és mozgásirányok (4. ábra) a középjátékosok szempontjából is sokrétűbb lett, ami azt jelenti, hogy a játékrendszerekben (Hoop Tactics, 2016), a taktikai repertoárokban, a centerek rendszeresen a hárompontos vonalon kívül is helyezkednek és ezáltal jóval többször kerülnek hárompontos dobóhelyzetbe (4. ábra). A dobóhelyzetek gyakoribb kialakulása miatt az edzéseken is rendszeresen gyakorolják a távoli dobásokat. Azzal, hogy a mozgásrendszerek miatt távolabb helyezkednek el a centerek a gyürűtől, egyben védőjüket is kihúzzák a büntetőterületről, megnyílik a hely a külső mezőnyjátékosok előtt a betörésekre. Ennek következtében viszont a centerek védőinek rendszeresen besegítést kell alkalmazniuk a csapatvédekezés

${ }^{1}$ A kosárlabda világában használt kifejezés, azok a játékosok, akiknek rendszeresen sikeres dobásaik vannak távolról.

${ }^{2}$ A kicsi játékosok a gyürütöl távolabbi, a nagyobbak pedig a gyürühöz közeli büntetö terület környékén vagy azon belüli pozíciókat foglalják el a támadás folyamán. 
alapelvei szerint (Ránky, 1999), ami által kénytelenek elhagyni az ellenfél támadó centereit, akik így a hárompontos vonalon kívül üresen maradnak. Egy

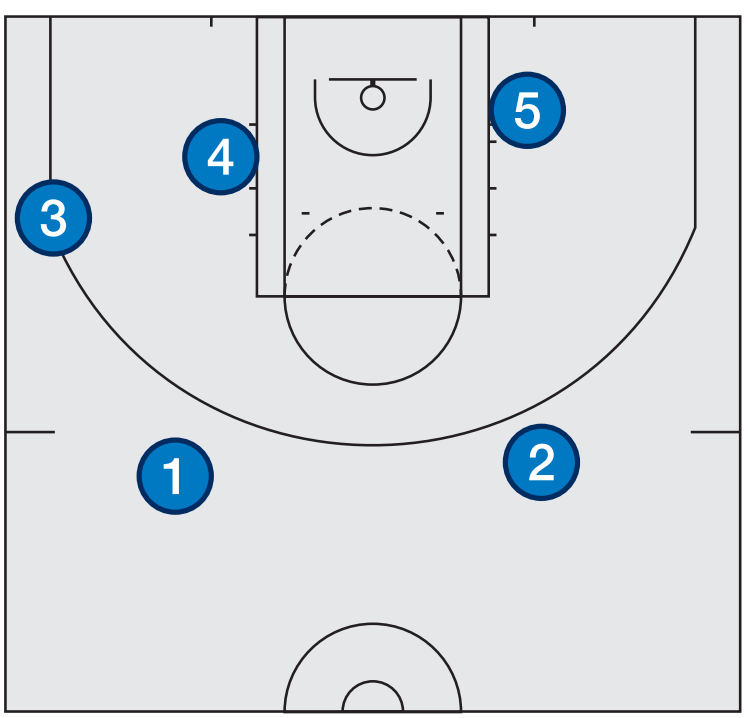

1: irányitó hátvéd; 2: dobó hátvéd; 3: bedobó; 4: eröcsatár „kis center”; 5: center

2. ábra. Dean Smith (North Carolina egyetem) alapfelállások, a centerek alsó (low post) és felső poszt (high post) (eredeti ábra: Figure 12.16, Coaching Basketball Jerry Kraus 159. o., 1994)
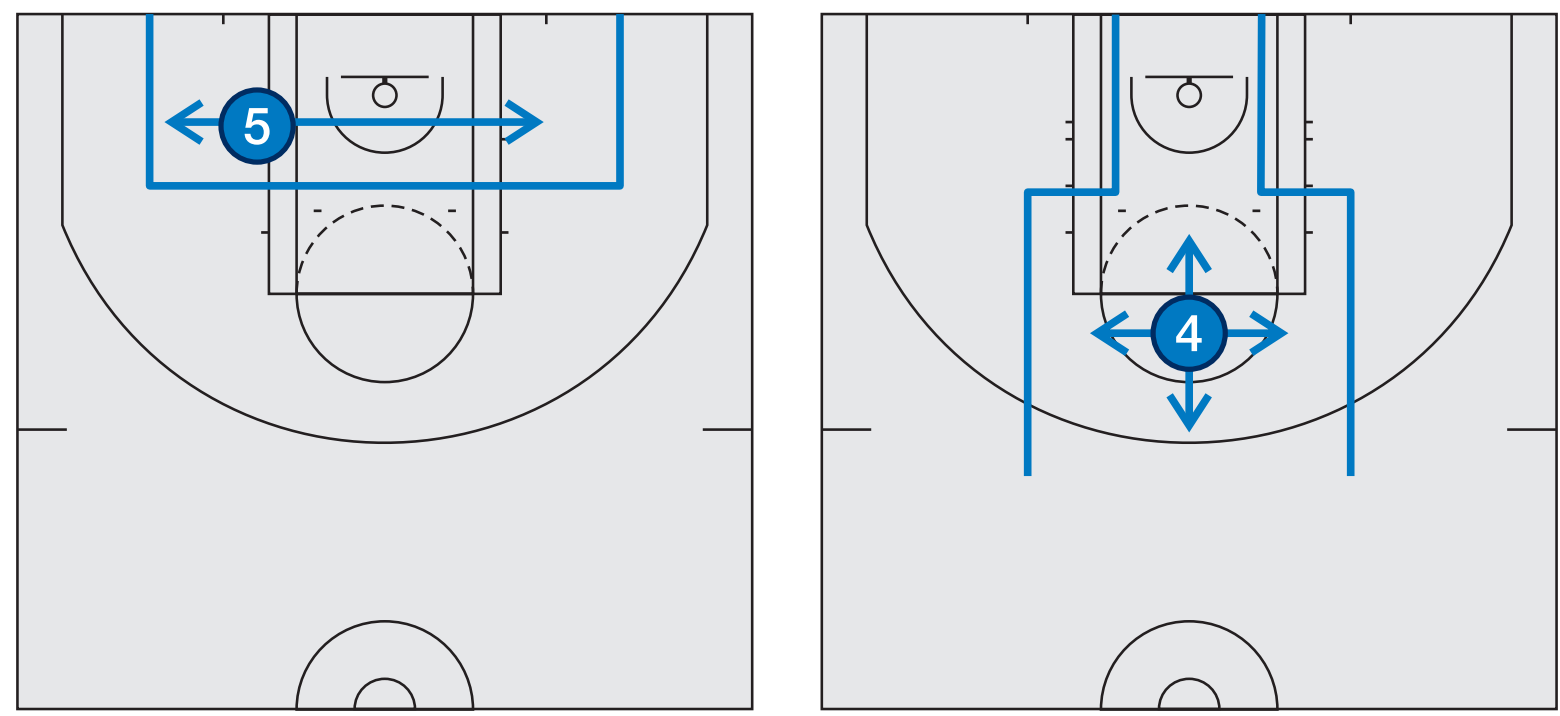

5: center és felsö poszt (high post); 4: eröcsatár „kis center”mozgásterülete

3. ábra. Dean Smith által meghatározott center alsó (low post) (eredeti ábra: Figure 12.16, Jerry Kraus, Coaching Basketball 159.o., 1994)

\section{Statisztika}

Mint minden objektíven mérhető kosárlabda játékelem, így a hárompontos dobások is megjelennek a mérkőzésekről készült statisztikában. A mérkőzések értékeléséhez egyre nagyobb adatbázis áll rendelkezésre, amire támaszkodva és hasznos elemzése által, közelebb juthatunk később a sikerhez. Ennek tipikus példája olvasható a Moneyball: Art of Winning an Unfair Game (Lewis, 2003) című könyvben. Általában a statisztikákra, mint a mérkőzés vagy játékos és csapat teljesítményértékelés eszközére, nagy hangsúlyt fektetnek a kosárlabda 
szakemberek. A most érvényben lévő hivatalos statisztikai módszer, amit a kosárlabda mérkőzéseken használnak, túlnyomórészt a támadással kapcsolatos adatokat rögzíti. Dean Oliver (2004) kiemeli a kosárlabda statisztika jelentőségét, fontosságát és felhasználási jelentőségét az edzők, sportvezetők és menedzserek részére. Fontosnak tartja az egyéni és csapat statisztika külön és egyben történő elemzését, de figyelmeztet arra is, hogy vannak olyan részei a kosárlabda mérkőzésnek, amit statisztikai

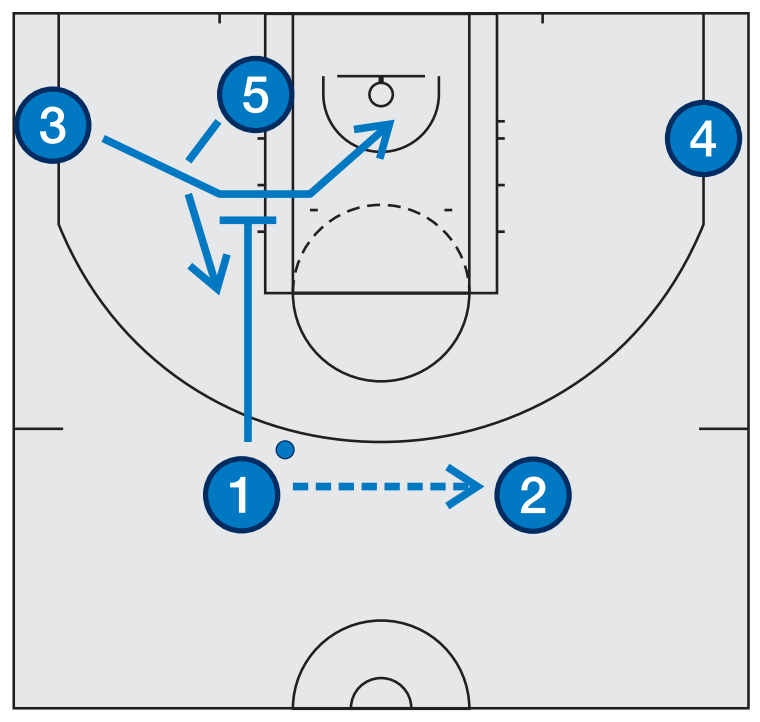

Egycenteres felállás mutatókkal nem, vagy csak nehezen lehet mérni. Ilyen például a védekezés. A hárompontos dobások jelentőségére és kihasználására készültek elemzések (Baker, Shea, 2016), ahol stratégiai elemként kezelik a távoli dobásokat. Egy másfajta statisztikai elemzés szerint (Sterbenz, 2007) a kosárlabda játékosok teljesítményértékelésének lehetősége a „pontosztás” módszere. Ebben a módszerben a védekezés hatékonyságát is lehet mérni.

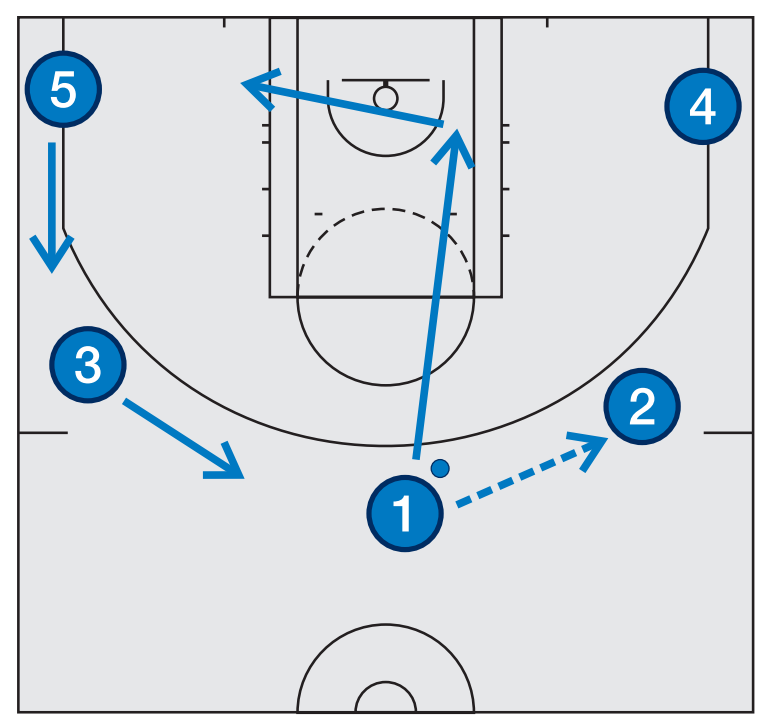

Nyitott, széles felállás

1: irányitó hátvéd; 2: dobó hátvéd; 3: bedobó; 4: eröcsatár „„kis center”; 5: center

4. ábra. Támadó felállások és mozgásirányok (eredeti ábra: Types of Offenses, Single Post, Four Out Motion Offenses; Open, Spread, Donut - Spread offenses; hooptactics.com, 2016)

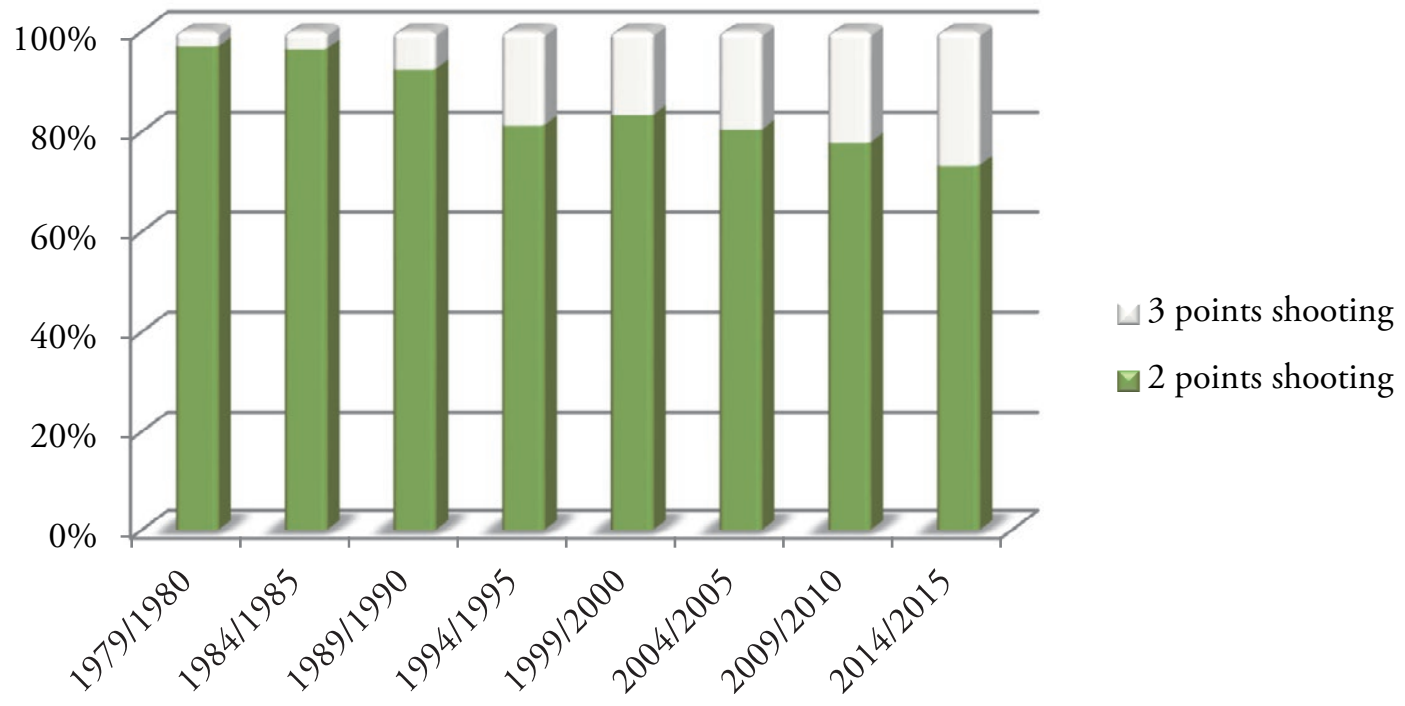

5. ábra. Két- és hárompontos mezőnydobások aránya az NBA-ban, szezonok szerint 
A közelmúltban az NBA statisztikai adatok alapján készült elemzése (Sterbenz, Bódi és Gulyás, 2015) rámutat, hogy a hárompontos dobások kísérletében folyamatosan növekvő tendencia látható bevezetése óta az Észak-Amerikai férfi kosárlabda bajnokságban (5. ábra). Ma már a hárompontos dobások száma megközelíti az összes dobások számának egyharmadát az NBA-ban, ami alátámasztja ennek a vizsgálatnak az eredményeit is. Ennek egyik oka, hogy az NBA vezető szerepet tölt be a mai kosárlabdában, amit az egész világ követ, illetve ebben a bajnokságban szereplő játékosok (USA és más nemzet játékosai) az olimpiákon résztvevő országok csapatainak meghatározó tagjai is.

\section{Hatékonyság}

Megállapíthatjuk, hogy ma már vannak olyan mérkőzések is, amikor egyes csapatoknak több három-, mint kétpontos kisérlete van. Érdekes

$$
e F G \%=\frac{F G+0.5 \times 3 P}{F G A}
$$

\section{FG: sikeres mezönydobások száma; 3P: sikeres 3 pontos dobások értéke; FGA: összes mezönydobás kisérlet}

\section{6. ábra. Hollinger-féle effektív dobószázalék számítás képlete (effective field goal percentage)}

A játékosok a mérkőzések során, nem ezt a fajta számítást veszik figyelembe amikor dobást hajtanak végre, hanem az adott helyzetből adódóan kísérelnek meg kosarat szerezni. Lehetőség szerint preferálják a több pontot érő dobást, mivel mint minden versenysportoló, saját teljesítményük maximalizálására törekszenek úgy, hogy mindent optimalizálnak, legyen az mozgás, döntéshozás, megfelelő szellemei állapot vagy sportáguk bármilyen szegmense, ami befolyásolhatja a sikerük elérését (Bar-Eli, Plassner és Raab, 2011). Ilyen szemszögből, érdekességként, megemlíthető az effektív dobószázalékszámítást vizsgálata, a feltörekvő sportágként egyre népszerűbb $3 \times 3$ kosárlabdajátékban (félpályán játszák három-három ellen). Ebben a sportágban még nagyobb jelentősége lehet az effektív dobószázalék számításának, ugyanis ebben a sportágban a közeli és középtávoli dobások (megegyezik az 5:5 elleni kosárlabda 2 pontos dobásaival) értéke egy pontot ér - 1-szeres szorzóval, míg a távoli dobások (megegyezik az 5:5 elleni kosárlabda hárompontos dobásaival) 2 pontot érnek - 2-szeres szórzóval számolandóak. Az a csapat, aki 60\%-os egypontos mutatóval rendelkezik, ugyanannyi pontot tud elérni, ha a 2 pontos dobásait csak 30\%-os hatékonysággal dobja. Természetesen ez matematika, ahogy Sterbenz (2006) is megfogalmazza cikkében a racionális játékot a sportban. Ez arra utal, hogyan tudjuk kiszámolni az úgynevezett támadó értéket a labdabirtokláson keresztül, ami segítheti az edzőket a racionális stratégia kialakításában. A kosárlabdapályán viszont nagyon sok körülmény befolyásolja a dobáskisérletek számát és hatékonyságát, csak hogy egyet említsünk: a védő csapat arra törekszik hogy a támadó csapat dobásszáma minél kevesebb legyen és az is rossz hatékonysággal történjen. Ennek ellenére, a tapasztalatok alapján lehet, hogy egy-egy mérkőzést meg lehet nyerni sok hárompontos dobással, viszont hosszútávon bajnokságot vagy világversenyt nyerni nem lehet; a két- és hárompontos kisérletek egyensúlyának megtartása feltétlenül szükséges a végső diadalhoz (Sterbenz, Bódi és Gulyás, 2015).

\section{Módszerek}

A bevezetés végén elemzett NBA statisztikai adataihoz hasonlóan (5. ábra), ugyanez megállapítható az olimpiai játékok mérkőzéseinek statisztikai 
mutatói alapján a hárompontos dobások száma növekedésére és hatékonyságára. Az olimpiákon 12 férfi kosárlabda csapat szerepel a különböző földrészekről, ahol összesen 76 mérkőzést játszanak a csoportmérkőzések és a helyosztók során. A kutatás a Szöul (1988) és Rio de Janeiro (2016) között rendezett olimpiai játékok 532 férfi kosárlabda mérkőzés statisztikai adatait dolgozza fel. Ezen belül a mérkőzések során vizsgálja a hárompontos dobásokat a kísérlet és sikeres dobások arányaiban, valamint posztok szerinti megoszlásban, kiemelve a centerek dobóteljesítményét, illetve az olimpiákon a hivatalosan regisztrált játékosok közül a center játékosok számát. Ezen kívül a kutatás kiterjed a csapatok Rio-i Olimpián nyújtott teljesítményére, ezen belül az elért helyezés, a mérkőzéseken átlagosan dobott pontok és a hárompontos dobások hatékonyságára. Mivel korábban jellemzőn csak a mezőnyjátékosoknak voltak hárompontos dobásaik, a cikk azt vizsgálja, hogy a csapatok és azon belül a centerek hárompontos dobásai hogyan változtak az elmúlt évtizedekben az olimpiákon lejátszott kosárlabda mérkőzéseken.

\section{Eredmények}

1988-ban Szöulban, az első olimpiai bevezetés óta, a játékosoknak mérkőzésenként átlagosan 18 (összesen 1380) hárompontos kísérlete volt (7. ábra és 1. táblázat). A nyolc vizsgált olimpián átlagosan 22-szer (összesen 1672) próbálkoztak a csapatok a hárompontos vonalon túlról dobni a mérkőzéseken. Ebben a mutatóban az Athéni Olimpia (2004) kiugróan magas volt; 25 kísérlet mérkőzésenként (összesen 1922), ami után csökkenés tapasztalható, de azt követően már ismét növekedést mutatnak a számok. Rio-ban ez a szám 23 (összesen 1781) volt. Az összes rádobás tekintetében, ha különválasztjuk a mezőnyjátékosok és a centerek hárompontos kísérleteinek számát, az látható, hogy 1988-ban a centerek összesen 23-szor próbálkoztak távoli dobással, amiből 6-szor voltak sikeresek, 26\%-os hatékonysággal.

Az összes sikeres hárompontos dobást elemezve, Szöulban csak 1\%-ot dobták a centerek, míg Rio de Janeiro-ban ez már 17\% volt, ami jelentős emelkedésnek mondható (2. táblázat). Érdekes, hogy az athéni olimpián kiugróan magas dobásszámhoz a középjátékosok aktív részvétele is kellett; a centerek 340 kísérletből 125 sikeres dobást hajtottak végre, 38\%-os hatékonysággal. Az ez utáni csökkenés azzal magyarázható, hogy 2004 után a csapatok védekezésükben sokkal jobban odafigyeltek az ellenfél centereinek hárompontos dobásaira, jelentős számú növekedésük miatt nagyobb hangsúlyt fektettek ezek megakadályozására.

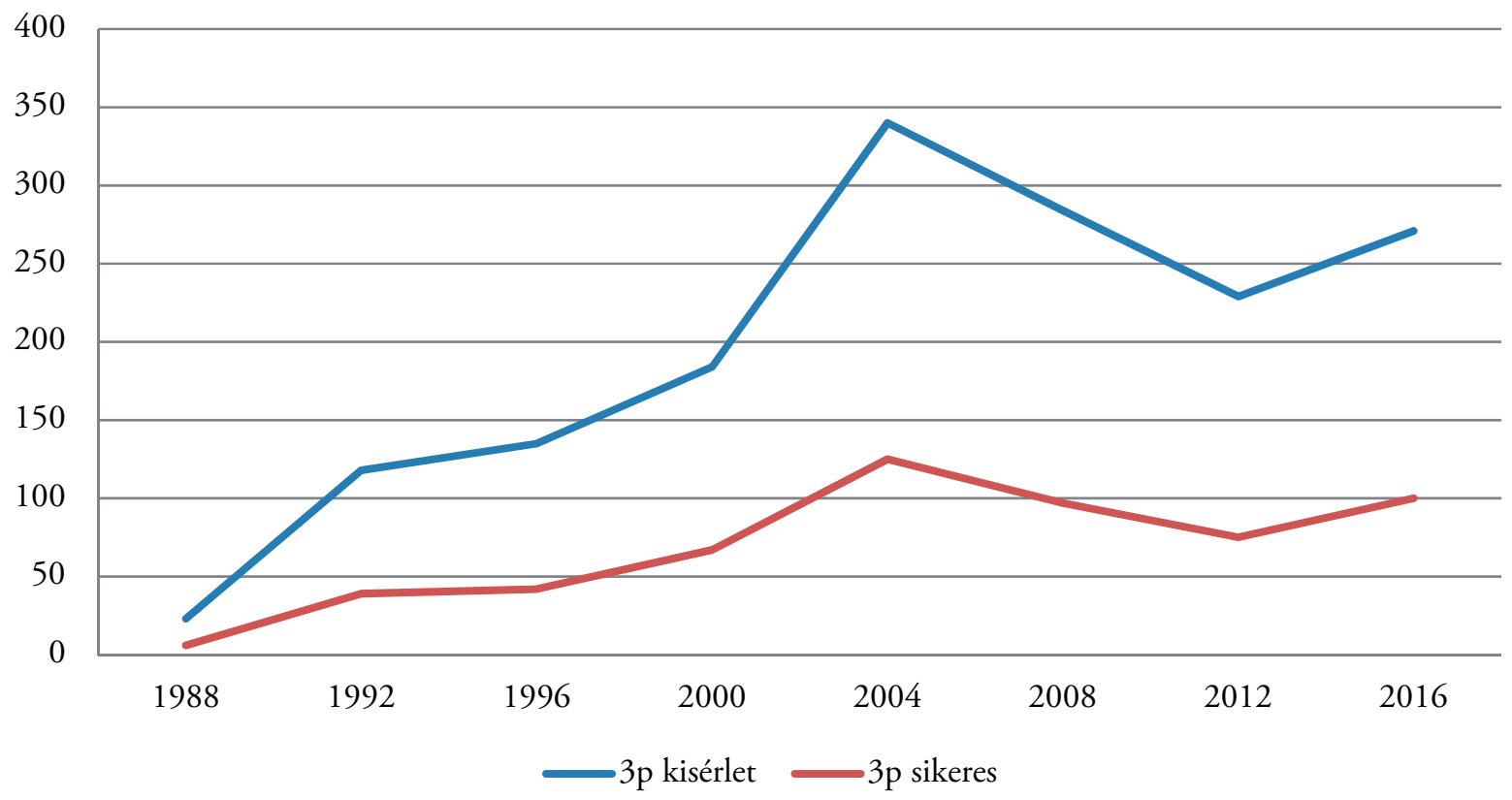

7. ábra. Centerek hárompontos kísérletei, sikeres dobások és hatékonyságuk az olimpiákon (forrás: wwwold.worldbasket.com) 
1. táblázat. Centerek hárompontos kísérletei, sikeres dobások és hatékonyságuk az olimpiákon (forrás: wwwold.worldbasket.com)

\begin{tabular}{|c|c|c|c|}
\hline \multicolumn{4}{|c|}{ Centerek hárompontos dobásai } \\
\hline Olimpia & Kísérlet & Sikeres & Hatékonyság (\%) \\
\hline 1988 & 23 & 6 & 26 \\
\hline 1992 & 118 & 39 & 33 \\
\hline 1996 & 135 & 42 & 31 \\
\hline 2000 & 184 & 67 & 36 \\
\hline 2004 & 340 & 125 & 38 \\
\hline 2008 & 284 & 97 & 34 \\
\hline 2012 & 229 & 75 & 33 \\
\hline 2016 & 271 & 100 & 37 \\
\hline
\end{tabular}

2. táblázat. Hárompontos kísérletek és sikeres dobások (1988 Szöul - 2016 Rio de Janeiro) (forrás: wwwold.worldbasket.com)

\begin{tabular}{|c|c|c|c|c|c|c|}
\hline \multicolumn{7}{|c|}{ Hárompontos dobások és megoszlása az olimpiákon } \\
\cline { 1 - 2 } Olimpia & $\begin{array}{c}\text { Kísérlet } \\
\text { Center } \\
\text { (poszt: 4,5)* }\end{array}$ & $\begin{array}{c}\text { Mezőny } \\
\text { (poszt: } 1-3)^{*}\end{array}$ & $\begin{array}{c}\text { Center } \\
\text { (poszt: } 4,5)^{*}\end{array}$ & $\begin{array}{c}\text { Mezőnyök } \\
\text { (poszt: } 1-3)^{*}\end{array}$ & $\begin{array}{c}\text { Összes } \\
\text { sikeres }\end{array}$ & $\begin{array}{c}\text { Center } \\
\text { sikeres / Összes } \\
\text { sikeres (\%) }\end{array}$ \\
\hline 1988 & 23 & 1357 & 6 & 526 & 532 & 1 \\
\hline 1992 & 118 & 1510 & 39 & 513 & 552 & 7 \\
\hline 1996 & 135 & 1680 & 42 & 626 & 668 & 6 \\
\hline 2000 & 184 & 1253 & 67 & 434 & 501 & 13 \\
\hline 2004 & 340 & 1582 & 125 & 573 & 698 & 18 \\
\hline 2008 & 284 & 1437 & 97 & 536 & 633 & 15 \\
\hline 2012 & 229 & 1465 & 75 & 524 & 599 & 13 \\
\hline 2016 & 271 & 1510 & 100 & 501 & 601 & 17 \\
\hline
\end{tabular}

* Mezöny: 1. Irányitó hátvéd, 2. Dobó hátvéd 3. Bedobó; Center: 4. Eröcsatár „Kis Center”, 5. Center

A növekvő tendenciát erősíti, illetve részben magyarázza az olimpiákon résztvevő centerek számának növekedése is. 12 férfi csapat vett részt a játékokon, ami azt jelenti, hogy 144 játékos szerepelt a mérkőzéseken. Ebből a 144 játékosból - hivatalos nevezés szerint -, 1988-ban 18 center vagy erőcsatár (4-es és 5-ös poszt) volt a csapatokban (3. táblázat), akik közül hat játékos kísérelt meg hárompontost dobni. 2016-ban Rio-ban már 51 középjátékos szerepelt a csapatokban, és már 30 játékosnak volt távoli dobáskísérlete. A középjátékosok számának növekedésével párhuzamosan növekszik dobáskísérleteik száma is, viszont arányaiban már jóval nagyobb a növekedés. Korábban a centerek 33\%-nak volt távoli dobáskísérlete, míg az idei olimpián ez már a centerek közel 60\%-ról mondható el. Értelemszerűen a centerek számának növekedésével a mezőnyjátékosok csökkenése tapasztalható, viszont az elmúlt négy olimpián ez stagnáló képet mutatott a korábbi arányok változásához képest. 
3. táblázat. A játékosok számának megoszlása posztok szerint az olimpiákon (forrás: wwwold.worldbasket.com)

\begin{tabular}{|c|c|c|c|}
\hline \multicolumn{4}{|c|}{ Játékosok posztok szerinti megoszlása } \\
\hline Olimpia éve & Centerek száma (fö) & Centerek sikeres 3 pontos (db) & Mezönyök száma (fö) \\
\hline 1988 & 18 & 6 & 124 \\
\hline 1992 & 35 & 12 & 107 \\
\hline 1996 & 40 & 26 & 101 \\
\hline 2000 & 48 & 25 & 96 \\
\hline 2004 & 56 & 38 & 88 \\
\hline 2008 & 52 & 33 & 93 \\
\hline 2012 & 51 & 28 & 93 \\
\hline 2016 & 51 & 30 & 90 \\
\hline
\end{tabular}

Mezőny: 1. Irányító hátvéd, 2. Dobó hátvéd 3. Bedobó; Center: 4. Erőcsatár „Kis Center” 5. Center

4. táblázat. A mérkőzéseken átlagosan dobott pont szerinti rangsor a 2016-os olimpián (forrás: fiba.com)

\begin{tabular}{|c|c|c|c|c|c|c|c|c|}
\hline \multicolumn{9}{|c|}{ A mérkőzéseken átlagosan dobott pontok } \\
\hline $\begin{array}{c}\text { He- } \\
\text { lye- } \\
\text { zés }\end{array}$ & Csapat & $\begin{array}{c}\text { Dobott } \\
\text { pont } \\
\text { átlag }\end{array}$ & $\begin{array}{c}\text { Összes } \\
\text { dobott }\end{array}$ & $\begin{array}{c}\text { Sikeres 3p - } \\
\text { rádobott 3p }\end{array}$ & $3 \mathrm{p} \%$ & $\begin{array}{c}\text { Átlag } \\
3 p-b o ́ l \\
\text { pont }\end{array}$ & $\begin{array}{c}\text { Átlag } \\
3 p \text {-ból } \\
\text { pont \% }\end{array}$ \\
\hline 1. & 1. & USA & 101 & 807 & $10.4-28.1$ & 37 & 31 & 31 \\
\hline 2. & 8. & Argentína & 86 & 519 & $11.3-32.3$ & 35 & 34 & 40 \\
\hline 3. & 3. & Spanyolország & 86 & 689 & $9.8-26.5$ & 37 & 29 & 34 \\
\hline 4. & 4. & Ausztrália & 85 & 683 & $7.4-22.3$ & 33 & 22 & 26 \\
\hline 5. & 2. & Szerbia & 83 & 665 & $7.4-22.3$ & 33 & 22 & 26 \\
\hline 6. & 9. & Brazília & 82 & 411 & $6.4-21.6$ & 30 & 19 & 23 \\
\hline 7. & 6. & Franciaország & 81 & 490 & $5.5-15.2$ & 36 & 17 & 21 \\
\hline 8. & 5. & Horváthország & 80 & 483 & $8.3-23.8$ & 35 & 25 & 31 \\
\hline 9. & 11. & Nigéria & 78 & 392 & $10.2-27.8$ & 37 & 31 & 40 \\
\hline 10. & 7. & Litvánia & 76 & 456 & $7.5-22.3$ & 33 & 23 & 30 \\
\hline 11. & 12. & Kína & 63 & 318 & $3.8-15.4$ & 35 & 11 & 17 \\
\hline 12. & 10. & Venezuela & 63 & 315 & $4.8-20.4$ & 24 & 14 & 22 \\
\hline
\end{tabular}

Rio de Janeiro, 2016

A Rio-i Olimpia 12 csapatából a legjobb nyolc közé kerültek nyolc mérkőzéssel, míg, akik a
9-12. helyért játszottak 7 mérkőzéssel fejezték be a sorozatot. Az elemzésben a rangsor az egy mérkőzésen átlagosan dobott pont szerint került 
meghatározásra (4. táblázat). Az utolsó két oszlopban az látható, hogy melyik csapat hány pontot dobott átlagosan mérkőzésenként hárompontosból és ez hány százaléka a mérkőzésen átlagosan dobott pontoknak. A kiemelkedően a legtöbb pontot az aranyérmet nyerő USA nemzeti válogatottja dobta, 8 mérkőzésen összesen 807 pontot, ami 101 pontos átlagot jelent. Ezeken a mérkőzéseken átlagosan 28.1 dobás kísérletük volt a hárompontos vonalon túlról, amiből átlagosan 10.4 ment be a gyürűbe, 37\%-os hatékonysággal. Ez azt jelenti, hogy a dobott 101 pontjukból átlagosan 31 pontot dobtak hárompontosból.

Ez megközelítőleg 30\%-a az átlagosan dobott pontnak. A rangsorban második legtöbb pontot dobó Argentína csapata 86 pontjából 34-et dobott hárompontosokból, ami 35\%-nak felel meg. Ez pontjaik közel 40\%-át teszi ki az összes dobott pontszámból, viszont ez csak a 8 . hely megszerzésére volt elegendő.

A rangsor alapján Spanyolország és Ausztrália ugyanazt a helyezést érte el, mint az olimpia végső helyezése. Ami még érdekes, hogy Szerbia csak 5. ebben a rangsorban átlagosan 83 dobott ponttal, úgy hogy ebből csak 22.3 pontot dobtak hárompontosból, 33\%-os hatékonysággal. Ez megközelítőleg pontjak 26\%-át tette ki, ez viszont ezüstérmet eredményezett. Szélsőséges értékeket mutat még Nigéria eredménye azzal, hogy a mérkőzésen szerzett pontjaiknak 40\%-át hárompontosokból szerezték, ami viszont csak a 11. hely megszerzésére volt elegendő.

\section{Összegzés}

Az elemzés során figyelembe vett statisztikai adatok alapján egyértelműen kijelenthető, hogy a mai kosárlabda mérkőzések meghatározó játékelemévé nőtte ki magát a középjátékosok hárompontos kísérleteinek és eredményességének száma.

Érdekességként megemlíthető, hogy a mai férfi kosárlabda csapatoknál, nem csak az olimpiai játékokon szereplő nemzeti válogatottaknál, hanem szinte minden nemzeti bajnokságban megfigyelhető, hogy csaknem minden csapatban van olyan center, akár 4-es vagy 5-ös pozícióban vagy mindkettőben, aki rendszeresen dob hárompontos kosarat a mérkőzések folyamán. Az eredményekből látszik, hogy az elmúlt négy olimpián megközelítőleg átlagosan ötször annyi hárompontos dobás kísérletük van a mezőnyjátékosoknak, mint a centereknek, viszont nem mindegy milyen hatékonysággal történik ez. Például, ha nem is nagy különbséggel, de a Rio-i Olimpián a centerek jobbnak bizonyultak ebben az összehasonlításban, hiszen a mezőnyjátékosok 33\%-kal, míg a centerek 37\%-os hatékonysággal céloztak a hárompontos vonalon túlról. Valószínúleg az üres helyzeteket dobták rá.

Ahogy az elemzésekből kiderült, Nigéria kosárlabda válogatottja hárompontos dobásaiból dobta pontjai 40\% százalékát (a 2016-os olimpia mezönyében a legtöbbet). Ennek ellenére, nem voltak olyan sikeresek, amiből az következik, hogy a játék más elemeiben is magas szinten kell továbbra is teljesíteni ahhoz, hogy az élmezőnyben végezzen egy csapat.

Nem elég a sok sikeres hárompontos dobás, amivel egy-egy mérkőzést meg lehet nyerni, viszont hosszú távon, bajnokságot vagy világversenyt nem.. A két- és hárompontos kisérletek egyensúlyának megtartsa feltétlenül szükséges a támadásban.

Egyre több centernek van hárompontos dobása a kosárlabda mérkőzéseken, ami további igazolása annak, hogy a posztok között a határvonalak egyre jobban elhalványulnak. Nincsenek már olyan nagy különbségek, mint korábban, sem a támadásban, sem a felállásban, sem a mozgásirányokban, sem a támadásban végrehajtott dobásfajtákban. A „kicsi kinn, nagy benn" elv már nem annyira érvényes. Vannak olyan 4-es vagy 5-ös poszton játszó centerek, akik fizikai képességeiknek, dinamikusságuknak, valamint technikai képzettségüknek köszönhetően, képesek hasonló mozgásokra, mint a mezőnyjátékosok. Ilyen a hárompontos dobás, a labdavezetés, az egy-egy elleni támadás nem csak a gyűrűhöz közeli pozícióból, hanem a hárompontos vonalon kívülről indítva is. Ennek az oka az, hogy a mai professzionális centerjátékosok edzői utánpótláskorukban nagy hangsúlyt fektettek képzésükre. Ezeknek a képzéseknek az alapelve, hogy az utánpótláskorban a magasabb gyerekek is, akikből centerek lehetnek, megkapják a centerképzés mellett ugyanazt a technikai képzést, mint a kisebb mezőnyjátékosok.

További elemzéseket kell végezni annak igazolására, hogy azok a csapatok sikeresebbek-e, ahol a centerek több hárompontos kosarat dobnak, illetve vizsgálat alá kell vetni a centerek két- és hárompontos dobásainak hatékonyságát, illetve el kell végezni azok összehasonlítását a Hollinger-féle valódi effektív dobószázalékos számítással. 


\section{Irodalom}

1. Baker, C., Shea, S. (2016): The Defensive 3-point Revolution, Basketball Analitics

2. Bar-Eli, M., Plessner, H, Raab, M. (2011): Judgement, Decision Making and Success in Sport, John Wiley\& Sons, Ltd., Publication, Chichester

3. Hollinger, J. (2005): Pro Basket Forecast, 2005-06 edition, Potomac Books, Inc. Dulles, Virginia

4. Kraus, J. (1994): Coahing Basketball, Master Press, Indianapolis

5. Lewis, M. (2003): Moneyball: The Art of Winning an Unfair Game, W.W. Northon \& Company

6. Ránky, M. (1999): Játék a Kosárlabda,a Kosárlabda Játék, PAUZ - Westermann, Celldömölk

7. Sterbenz, T. (2006): The Rational Game, FIBA ASSIST, 20, 20-23.Publication of FIBA International Basketball Federation, 2006 Június szám
8. Sterbenz, T. (2007): Teljesitményértékelés a Professzionális Kosárlabdában, Vezetéstudomány XXXVIII. Évf. 2007. 1. szám

9. Sterbenz, T., Bódi, B., Gulyás, E. (2015) Equilibrium in Basketball ShootingSelection, Kézirat

10. Wooden, J. R. (1999): Practial Modern Basketball, third edition, Viacom Company, Needham Heights

\section{Internet források}

11. www.basketballanalistibook.com, letöltés ideje: 2016. 12.21. 11.00

12. www.hooptactics.com, letöltés ideje: 2016. 12.20. 17.30

13. www.nba.com, letöltés ideje: 2016 11. 25. 16.00

14. www.fiba.com, letöltés ideje: 2016 11. 26. 10.15

15. wwwold.worldbasket.com, letöltés ideje: 2016 11. 26. 14.00 